\title{
COMPARISON OF THE EFFECTIVENESS ONLINE AND OFFLINE REGISTRATION SYSTEM ON PATIENT WAITING TIME IN PRIMARY HEALTH CARE SEMARANG USING QUEUING THEORY
}

\author{
${ }^{1}$ Evina Widianawati, ${ }^{2}$ Faik Agiwahyuanto, ${ }^{3}$ Trianni, ${ }^{4}$ Adelia Ayu Sabrina, ${ }^{5}$ Dimas Angga Febian \\ ${ }^{12345}$ Health Informatic Manajemen, Faculty of Health, Universitas Dian Nuswantoro \\ www.dinus.ac.id \\ 1evina.widianawati@dsn.dinus.ac.id,2faik.agiwahyuanto@dsn.dinus.ac.id, \\ 3422201702165@mhs.dinus.ac.id,4422201702172@mhs.dinus.ac.id,5422201702194@mhs.dinus.ac.id
}

\begin{abstract}
Abstrak
Sistem pendaftaran online di Primary Health Care semarang sudah mulai diterapkan di tahun 2018, namun pengguna pendaftaran online masih sedikit. Tujuan penelitian ini adalah untuk membandingkan keefektifan pendaftaran online dan offline pada waktu tunggu menggunakan variable dalam teori antrian. Penelitian pada 3 Primary Health Care di kota semarang. dengan melakukan observasi waktu kedatangan dan waktu masuk poli pasien kemudian pasien juga diberikan lembar kuesioner kepuasan pelayanan pendaftaran. Data diolah dengan menggunakan variable teori antrian serta analisis statistik deskriptif dan inferensial. Jumlah pendaftar online hanya $12 \%$ sedangkan $88 \%$ mendaftar offline. Jumlah total kedatangan pasien pendaftar online per jam 0,85 pasien dan pendaftar offline 6,38 pasien per jam dimana pasien banyak datang di 105 menit awal buka puskesmas. Utilitas server registrasi pendaftar online $7 \%$ sedangkan offline $48 \%$ tergolong rendah dan antrian pasien hanya sekitar 1 pasien sehingga tidak diperlukan server registrasi tambahan untuk mempercepat pelayanan. Terdapat perbedaan antara waktu tunggu pendaftaran online dan offline $(p=0,00)$ dimana pasien online menunggu 4,91 menit sedangkan pasien offline menunggu 8,84 menit. Terdapat pengaruh waktu tunggu dalam sistem pada kepuasan pasien $(p=0,00)$ sehingga untuk meningkatkan kepuasan pasien diharapkan pasien melakukan registrasi online.
\end{abstract}

Kata Kunci: Pendaftaran online; Waktu tunggu; Teori Antrian

\begin{abstract}
The online registration system at Semarang's Primary Health Care has been implemented in 2018, but online registration users are still small. The purpose of this study was to compare the effectiveness of online and offline registration at waiting times using variables in queuing theory. Research at 3 health centers in the city of Semarang. By observing the time of arrival and time of admission to the patient's clinic then the patient is also given a registration service satisfaction questionnaire sheet. The data were processed using queuing theory variables as well as descriptive and inferential statistical analysis. The number of online registrants is only $12 \%$ while $88 \%$ registered offline. The total number of online registrant patient arrivals per hour is 0.85 patients and offline registrants are 6.38 patients per hour where many patients arrive at the first 105 minutes to open the puskesmas. The utility of the online registrant registration server is $7 \%$, while $48 \%$ offline is classified as low and the patient queue is only about 1 patient so there is no need for an additional registration server to speed up service. There was a difference between online and offline registration waiting times $(\mathrm{p}=0.00)$ where online patients waited 4.91 minutes while offline patients waited 8.84 minutes. There is an effect of waiting time in the system on patient satisfaction $(p=0.00)$ so that to increase patient satisfaction, it is hoped that patients will register online.
\end{abstract}

Keywords: Online Registration; Waiting Time; Queuing Theory

\section{INTRODUCTION}

Semarang City Health Office launched the Pustaka (Primary Health Care Without Queuing Kota Semarang) application on July 1, 2018, to improve the quality of health services so that patients can register online to reduce queues at Primary Health Care (Health office Semarang,
2018). Online registration by way of patients does not need to come to health care facilities first to get the queue number becomes one way to reduce the queue and waiting time of patients (Masniah, 2015). But in fact, online registration through Pustaka still lacks the attention of the people of Semarang City. One of the causes of low online registration users is because after the patient performs online 
registration, the patient still has to register the code obtained when registering online to the registration officer and still queuing at the poly so this problem makes the patient prefer to register offline.

Patient waiting time is the main point to note to improve the quality of health care facilities (Oostrom, Einav, \& Finkelstein, 2017). Long patient waiting times will result in decreased patient satisfaction and disrupt the practice schedule (Chu, Westbrook, Njue-Marendes, Giordano, \& Dang, 2019)(Kreitz, Winters, \& Pedowitz, 2016)(Kagedan, Edge, \& Takabe, 2021). The re-registration of online applicants on the registration server needs to be reviewed on the effectiveness of online registration on the decrease in inpatient waiting time. Analysis of online and offline registration queue systems can be done using queue theory to make the queue system more efficient. Queue theory is a mathematical theory that calculates queues and waits for times (Yakubu \& Najim, 2014)(Yaduvanshi, Sharma, \& More, 2019). Queue theory variables include the number of patient arrivals, server utilities, queue length, and patient waiting times used to compare the effectiveness of online and offline registrations (Supriyadi, Alfarisi, Karno, \& Cahyadi, 2019).

From the results of Saremi research, it is known that online registration is an effective solution in scheduling patient and doctor meetings (Saremi A, Jula P, ElMekkawy T, 2015). Cao's research in China found that the online registration system effectively increases satisfaction and reduces the waiting time of online registrant patients (Cao et al., 2011). However, there has been no analysis of the comparative effectiveness of online and offline registration systems on patient waiting times using queue theory variables. Therefore, the purpose of this study is to find out the comparison of the effectiveness of online and offline registration on patient waiting times at the Semarang City Health Center using queue theory.

\section{RESEARCH METHOD}

This research uses quantitative research with a cross-sectional approach. The study was conducted with observation to 3 Primary Health Care in February 2020 using the queue system observation sheet instrument and then the patient was given a patient satisfaction questionnaire sheet.

Offline registrant patients at the beginning come to the Primary Health Care must register to the registration server then get the queue number, while the online registrant patients register online and then show SMS/WhatsApp reply to be confirmed on the registration server and given the queue number. A patient who registers online faster gets the queue number because there is no need to fill in the data on the registration server that only shows the online registration code. After getting the queue number to the poly then the patient online and offline wait in the queue seat to get into the poly. To clarify the description of the queue system flow and research variables in Primary Health Care is shown in figure 1 below.

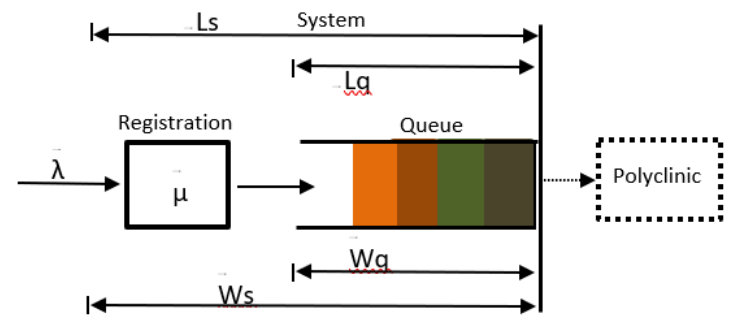

Figure 1. Queue system flow and research variables

The data collected is the time of coming to the Primary Health Care and the time of arrival of poly as well as patient satisfaction data on the registration service Likert scale 1-5 with 8 questions. The data is processed using queue theory variables as well as descriptive and inferential statistical analysis. The research variables used include variables contained in the queue theory shown in table 1 below (Dharmawirya \& Adi, 2012).

Table 1. Research Variables and Notation

\begin{tabular}{clc}
\hline Variable & Explanation & Formula \\
\hline$\lambda$ & Patient arrival rate & AVG of patient/ hour \\
$\mu$ & Patient service rate & $\lambda^{*}(\mathrm{~L}+1) / \mathrm{L}$ \\
$\mathrm{N}$ & Number of servers & - \\
$\mathrm{P}$ & System utility & $\lambda / \mu$ \\
$\mathrm{Ls}$ & Number of patients in the system & $\lambda^{*} \mathrm{~W}$ \\
$\mathrm{Lq}$ & Queue length in queue period & - \\
$\mathrm{Ws}$ & Time spent in the system & - \\
$\mathrm{Wq}$ & Waiting time in queue period & $\mathrm{Lq} / \lambda$ \\
\hline
\end{tabular}

Variables in queue theory are used to determine the difference between online and offline applicants in terms of several patient arrivals, server utilities, queue length, and patient waiting time. It is known that the number of online and offline registration servers is 1 registration server. $\lambda$ calculated by calculating the number of arrivals at 7-12 hours then divided by 5 . Ws were obtained by calculating the average waiting time of the patient. Lq is obtained by calculating the average number of queues per patient. Another variable is obtained from the calculation result according to the formula above.

Descriptive analysis to illustrate the difference in the number of visitors and patient satisfaction score between online and offline registration in puskesmas. Normality test analysis is 
used to test the normality of waiting for time data and online and offline patient satisfaction data. The chi-square test was conducted to determine the characteristic relationship of respondents with the selection of online or offline registration. An independent sample t-test is conducted to find out the comparison of waiting time and satisfaction in online and offline applicants. Linear regression tests are conducted to determine the effect of waiting times on patient satisfaction.

\section{RESULT AND DISCUSSION}

The results of the descriptive analysis of respondent characteristics are presented in table 2 below.

Table 2. Descriptive analysis of respondents' characteristics of Online and Offline Registration

\begin{tabular}{|c|c|c|c|c|c|c|}
\hline \multirow{2}{*}{\multicolumn{2}{|c|}{ Characteristic Participant }} & \multicolumn{3}{|c|}{ Frequency } & \multirow{2}{*}{$\begin{array}{l}\% \text { Online } \\
\text { to Total }\end{array}$} & \multirow{2}{*}{$\begin{array}{c}\text { Sig Characteristic to } \\
\text { Registration }\end{array}$} \\
\hline & & Online & Offline & Total & & \\
\hline \multirow{2}{*}{ Sex } & Men & 13 & 81 & 94 & $14 \%$ & \multirow{2}{*}{$0,449^{*}$} \\
\hline & Women & 21 & 174 & 195 & $11 \%$ & \\
\hline \multirow{4}{*}{ Age } & $<=20$ th & 3 & 30 & 33 & $9 \%$ & \multirow{4}{*}{$0,397^{*}$} \\
\hline & $21-35$ th & 20 & 112 & 132 & $15 \%$ & \\
\hline & $35-50$ th & 6 & 51 & 57 & $11 \%$ & \\
\hline & $>50$ th & 5 & 62 & 67 & $7 \%$ & \\
\hline \multirow{6}{*}{ Occupation } & Employee & 12 & 88 & 100 & $12 \%$ & \multirow{6}{*}{$0,473^{*}$} \\
\hline & Housewife & 14 & 69 & 83 & $17 \%$ & \\
\hline & Student & 4 & 39 & 43 & $9 \%$ & \\
\hline & Enterpreneur & 3 & 35 & 38 & $8 \%$ & \\
\hline & Pensionary & 1 & 15 & 16 & $6 \%$ & \\
\hline & Others & 0 & 9 & 9 & $0 \%$ & \\
\hline \multirow{6}{*}{$\begin{array}{c}\text { Last } \\
\text { Education }\end{array}$} & Not go to School & & 7 & 7 & $0 \%$ & \multirow{6}{*}{$0,272^{*}$} \\
\hline & Primary School & 5 & 30 & 35 & $14 \%$ & \\
\hline & Middle School & 4 & 28 & 32 & $13 \%$ & \\
\hline & High School & 17 & 118 & 135 & $13 \%$ & \\
\hline & Diploma & & 31 & 31 & $0 \%$ & \\
\hline & Bachelor & 8 & 41 & 49 & $16 \%$ & \\
\hline
\end{tabular}

*p-value Chi-square test

From the results of table 2, it is known that the characteristics of respondents who use online registration as much as $14 \%$ are male, $15 \%$ are around the age of 20-35 years, $16 \%$ of the last education is undergraduate and $17 \%$ work as a housewife. From the results of the test correlation characteristics of respondents with the selection of online or offline registration using chi-square test known p-value of gender, age, education, and occupation $>=0.05$ so that there is no relationship of respondent characteristics with the selection of online or offline registration. This means that gender, age, education, and employment do not affect online or offline registration selection. Furthermore, the results of the analysis of the effectiveness of online and offline registration based on queue theory and statistical comparison test are presented in table 3 and table 4 below.

Table 3. The results of Variable Analysis of Online and Offline Registration Queue Theory

\begin{tabular}{|c|c|c|c|c|}
\hline \multirow{2}{*}{\multicolumn{2}{|c|}{ Description }} & \multicolumn{3}{|c|}{ Registration } \\
\hline & & Online & Offline & All \\
\hline \multirow{2}{*}{ Participant } & $\mathrm{f}$ & 34 & 255 & 289 \\
\hline & $\%$ & $12 \%$ & $88 \%$ & $100 \%$ \\
\hline \multirow{2}{*}{ Statisfaction } & AVG Score & 4,551 & 4,457 & 4,468 \\
\hline & $\mathrm{f}($ Score $>4)$ & 34 & 235 & 269 \\
\hline \multirow{8}{*}{ 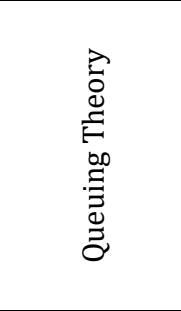 } & $\lambda$ & 0,85 & 6,38 & 7,23 \\
\hline & $\mu$ & 13,07 & 13,16 & 14,38 \\
\hline & $\mathrm{N}$ & 1 & & 1 \\
\hline & $\rho$ & $7 \%$ & $48 \%$ & $50 \%$ \\
\hline & Ls & 0,07 & 0,94 & 1,01 \\
\hline & Ws & 4,91 & 8,84 & 8,38 \\
\hline & $\mathrm{Lq}$ & 0,06 & 0,87 & 0,841 \\
\hline & $\mathrm{Wq}$ & 4,15 & 8,23 & 6,98 \\
\hline
\end{tabular}


Table 4. Online and Offline Registration Statistics Comparison Test Results

\begin{tabular}{|c|c|c|c|c|c|}
\hline \multirow{2}{*}{ Variable } & \multicolumn{2}{|c|}{ Normality test } & \multicolumn{2}{|c|}{ Difference Test } & \multirow{2}{*}{$\begin{array}{c}\text { Impact } \\
\text { test }\end{array}$} \\
\hline & Online & Offline & Online & Offline & \\
\hline Ws & 0,000 & 0,000 & \multicolumn{2}{|c|}{$0,000^{*}$} & \multirow{2}{*}{$0,000^{* *}$} \\
\hline Statisfaction & 0,000 & 0,000 & \multicolumn{2}{|c|}{$0,295^{*}$} & \\
\hline
\end{tabular}

From table 3 it is known that only $12 \%$ of patients register online, the rest register offline. The online registration patient satisfaction score is 4.55 on a scale of 5 and all online patients score above 4 on a scale of 5 . The arrival rate of online patients is only 0.85 / hour meaning only 0.85 patients every hour who register online while the arrival rate of offline applicants is 6.38 /hour. The utility of online registration server usage is only $7 \%$ while the number of offline registration server usage is $48 \%$. The utility of online and offline server users is still below $50 \%$. The length of the queue in the online and offline patient system is 1.01 which means there is a queue of 1.01 patients throughout the system from the beginning of admission to the Primary Health Care to the time of the entry of poly.

The length of queues in the online and offline patient queuing period was 0.841 meaning there was a queue of 0.841 patients from the completion of registration to the poly entry time. The length of the queue in the system and the length of the queue in the online and offline patient queue period are around 1 patient, meaning that if the patient enters the Primary Health Care then there will be a queue in the system and a queue waiting to poly as much as 1 patient queue. The waiting duration in the online patient system is 4.91 minutes while the waiting duration in the offline patient system is 8.84 minutes. The waiting duration in the online patient queue period is 4.15 minutes while the waiting duration in the offline patient queue period is 6.98 minutes. The waiting duration in the system and the queue period by online patients are lower than in offline patients. Offline patients waited in the system 3.93 minutes longer compared to online patients.

Based on the results of the normality test waiting time in the online and offline registration system obtained $p$-value $<0.05$ so that the data is normally distributed so that the appeal test used is an independent test sample t-test. Based on the results of the independent appeal test sample t-test waiting time in the online and offline registration system obtained a p-value of $0.000<0.05$ so that there is a difference between online and offline registration waiting times.

Based on the results of the normality test satisfaction of online and offline registration patients obtained a p-value $<0.05$ so that the data is normally distributed so that the appeal test used is an independent test sample t-test. Based on the results of the independent appeal test sample t-test online patient satisfaction and offline registration obtained a p-value of $0.295<0.05$ so there is no difference between patient satisfaction online and offline registration. Based on the test results the effect of waiting time in the system on patient satisfaction obtained a p-value of $0.000<0.05$ so that there is an influence of waiting time in the system on patient satisfaction. Furthermore, the results of the number of patient arrivals $(\lambda)$ and the number of queues in the queue period (Lq) as well as the waiting time in the system (Wq) in every 15 minutes are presented in figures 1 and 2 below.

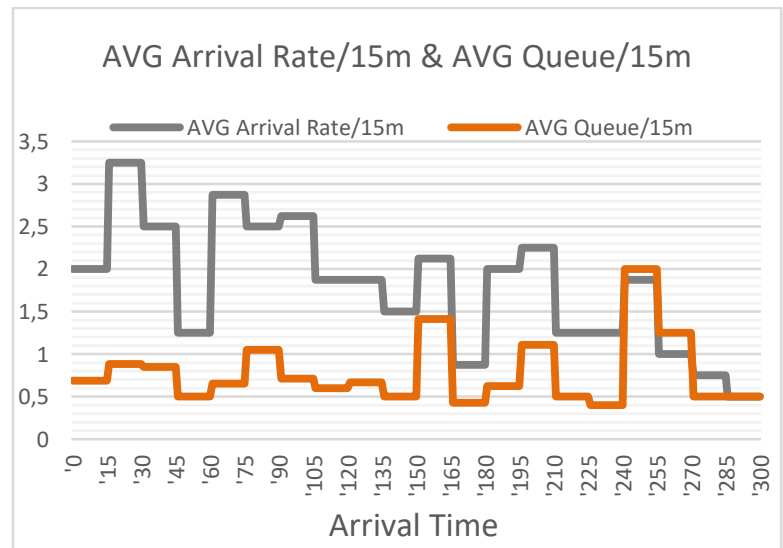

Figure 2 AVG Arrival Rate $(\lambda)$ \& Queue (Lq) each 15 minutes

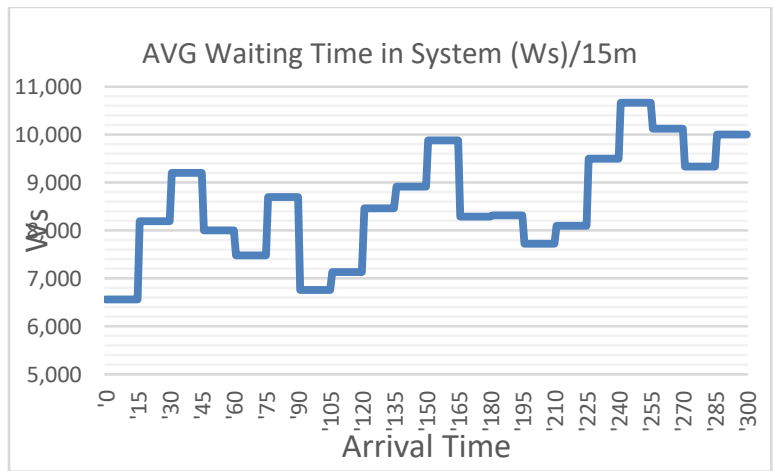

Figure 3 AVG Waiting Time (Ws) each 15 minutes

From figure 2 it is known that the most patient arrival time is at the 15th-30th minute and in the 60th-75th minute, the number of patient arrivals begins to decrease after the 105th minute. 
From these results, it can be interpreted that the initial 105 minutes is a rush hour for Primary Health Care where many patients arrive in the first 105 minutes of opening the puskesmas. The number of queues in the queue period is stable in the opening hours but the number of queues increases at the end of the Primary Health Care closure. The number of queues in the queue period tends to follow the number of patient arrivals, when the number of patient arrivals rises, the number of queues also rises. From figure 3, it is known that the waiting time of the patient increases at the end of the closing hours of the puskesmas

From the results of the study it is known that $12 \%$ register online, $88 \%$ register online where the characteristics of respondents in terms of gender, age, education, and work have no effect on the selection of online or offline registration. The results of online registrant research in Iranian hospitals also showed that the average online registrant is only about $13 \%$ which indicates that online applicants are still low and the quality needs to be improved (Samadbeik et al., 2018). From the results of the analysis of the variable theory of queues, it is known that the number of arrivals of offline registrant patients every hour ranges from 6.38 patients with online applicants only 0.85 patients per hour where many patients arrive in the first 105 minutes of opening the puskesmas. By knowing the patient's arrival time, it can help in allocating staff (Xavier et al., 2018). Based on the results of Lq and Ls known there are queues in the system and queues waiting to poly as much as 1 queue of patients where the queue is included a little. The utility of the offline server $48 \%$ and online $7 \%$ is still below $50 \%$, the server utility is fairly low and the patient queue is only 1 patient so no additional registration server is needed to speed up the service.

Statistical test results are known to be the difference between online and offline registration waiting times. The waiting duration in the system and the queue period by online patients were lower than in offline patients where online patients waited 4.91 minutes while offline patients waited for 8.84 . This is because online registrant patients only show the online registration confirmation code and do not need to fill in the data on the registration server such as offline applicants so that the waiting duration of online patients is less than offline patients. The results of the online registration study by Shen also mentioned that online registration can reduce the waiting time of patients (Shen, Yang, \& Sun, 2019). The result of online and offline patient waiting time is less than 15 min classified as low waiting time so that the patient will still be in the queue, if the waiting time is more than 15 minutes it will cause patient dissatisfaction (Aziati, Tun, Onn, Salsabilah, \& Hamdan, 2018).

In terms of satisfaction, it is known that there is no difference between online and offline registration patient satisfaction where the online registration patient satisfaction score is 4.55 while offline is 4.45 . The results showed there was an influence on waiting times in the system on patient satisfaction. This is in contrast to the results of Xie's study which stated that waiting times do not affect patient satisfaction (Xie \& Or, 2017)(Glogovac, Kennedy, Weisgerber, Kakazu, \& Grawe, 2020). The online and offline patient satisfaction score of 4,468 on a scale of 5 is classified as high because the patient waiting time is relatively low at 8.38 minutes.

\section{CONCLUSION}

Online applicants were only $12 \%$ where respondents' characteristics did not affect offline and online registration selection. The total number of online registrant patient arrivals per hour was 0.85 patients and offline applicants were 6.38 patients per hour. The number of arrivals of onlineoffline applicant patients per hour 7.23 patients where patients arrived in the first 105 minutes open the puskesmas. The utility of the online registrant registration server is $7 \%$ while offline $48 \%$ is relatively low and the queue of patients is low so no additional registration server is needed to speed up service. Online registrant patient waiting times are lower than offline patients so online registration is more effective in reducing patient waiting times. There is an effect of waiting times in the system on patient satisfaction to improve patient satisfaction it is expected that patients register online. Socialization is needed to the public for online applicants to increase, as well as online system improvements are needed so that online participants do not have to re-register on the Primary Health Care registration server to speed up services. In the next study, it is expected that there is an in-depth study on patient waiting time from the beginning of entry to exit of the Primary Health Care including poly, lab, and pharmacy waiting times so that it will get an overview of the total waiting time of patients in the Puskesmas.

\section{ACKNOWLEDGEMENT}

Researchers thanked the Semarang City Health Office and the Faculty of Health of Dian Nuswantoro University for supporting and assisting in providing information for this study. 


\section{REFERENCE}

Aziati, A. H. N., Tun, U., Onn, H., Salsabilah, N., \& Hamdan, B. (2018). Application Of Queuing Theory Model And Simulation To Patient Flow At The Outpatient Department. Proceedings of the International Conference on Industrial Engineering and Operations Management Bandung, Indonesia, March 6-8, 2018, (December 2019).

Cao, W., Wan, Y., Tu, H., Shang, F., Liu, D., Tan, Z., ... $\mathrm{Xu}$, Y. (2011). A web-based appointment system to reduce waiting for outpatients: A retrospective study. BMC Health Services Research, 11. https://doi.org/10.1186/14726963-11-318

Chu, H., Westbrook, R. A., Njue-Marendes, S., Giordano, T. P., \& Dang, B. N. (2019). The psychology of the wait time experience - What clinics can do to manage the waiting experience for patients: A longitudinal, qualitative study. BMC Health Services Research, 19(1), 1-10. https://doi.org/10.1186/s12913-019-43010

Dharmawirya, M., \& Adi, E. (2012). Case Study for Restaurant Queuing Model. SSRN Electronic Journal, 6, 52-55. https://doi.org/10.2139/ssrn.2014470

Glogovac, G., Kennedy, M. E., Weisgerber, M. R., Kakazu, R., \& Grawe, B. M. (2020). Wait Times in Musculoskeletal Patients: What Contributes to Patient Satisfaction. Journal of Patient Experience, $\quad 7(4), \quad 549-553$. https://doi.org/10.1177/237437351986482 8

Health office Semarang. (2018). Pustaka, now check to Primary Health Care no need to queue!

Kagedan, D. J., Edge, S. B., \& Takabe, K. (2021). Behind the clock: elucidating factors contributing to longer clinic appointment duration and patient wait time. BMC Health Services Research, 21(1), 1-9. https://doi.org/10.1186/s12913-02106079-y

Kreitz, T. M., Winters, B. S., \& Pedowitz, D. I. (2016). The Influence of Wait Time on Patient Satisfaction in the Orthopedic Clinic. Journal of Patient Experience, 3(2), 39-42. https://doi.org/10.1177/237437351665225 3

Masniah. (2015). An Implementation of Outpatient Online Registration Information System of
Mutiara Bunda Hospital. (IJARAI) International Journal of Advanced Research in Artificial Intelligence, 4(12), 9-16.

Oostrom, T., Einav, L., \& Finkelstein, A. (2017). Outpatient office wait times and quality of care for medicaid patients. Health Affairs, 36(5), 826-832. https://doi.org/10.1377/hlthaff.2016.1478

Samadbeik, M., Saremian, M., Garavand, A., Hasanvandi, N., Sanaeinasab, S., \& Tahmasebi, H. (2018). Assessing the online outpatient booking system. Shiraz E Medical Journal, 19(4). https://doi.org/10.5812/semj.60249

Saremi A, Jula P, ElMekkawy T, W. G. (2015). Bicriteria appointment scheduling of patients with heterogeneous service sequences. Expert Syst Appl, 42(8).

Shen, X., Yang, W., \& Sun, S. (2019). Analysis of the impact of China's hierarchical medical system and online appointment diagnosis system on the sustainable development of public health: A case study of Shanghai. Sustainability (Switzerland), https://doi.org/10.3390/su11236564

Supriyadi, S., Alfarisi, S., Karno, R., \& Cahyadi, D. (2019). Queue Design of Bank Teller Service in Banten, Indonesia. 165-171. https://doi.org/10.4108/eai.24-102018.2280631

Xavier, G., Crane, J., Follen, M., Wilcox, W., Pulitzer, S., \& Noon, C. (2018). Using Poisson Modeling and Queuing Theory to Optimize Staffing and Decrease Patient Wait Time in the Emergency Department. Open Journal of Emergency Medicine, 06(03), 54-72. https://doi.org/10.4236/ojem.2018.63008

Xie, Z., \& Or, C. (2017). Associations between waiting times, service times, and patient satisfaction in an endocrinology outpatient department: A time study and questionnaire survey. Inquiry (United States), 54. https://doi.org/10.1177/004695801773952 7

Yaduvanshi, D., Sharma, A., \& More, P. V. (2019). Application of queuing theory to optimize waiting-time in hospital operations. Operations and Supply Chain Management, 12(3), 165-174. https://doi.org/10.31387/oscm0380240

Yakubu, A., \& Najim, U. (2014). An Application of Queuing Theory to ATM Service Optimization: A Case Study. Mathematical Theory and Modeling, 4(6), 11-24. 